\title{
Pengaruh Premium Growth Ratio, Risk Based Capital Dan Hasil Investasi Terhadap Profitabilitas Perusahaan Asuransi Umum Yang Terdaftar Di Bursa Efek Indonesia Tahun 2010-2014
}

\begin{tabular}{|c|c|}
\hline \multicolumn{2}{|c|}{$\begin{array}{l}\text { Fira Agustin }^{1} \text { Asri Suangga }{ }^{2} \text { Bambang Sugiharto } \\
\text { Sekolah Tinggi Ilmu Ekonomi Sutaatmadja Subang } \\
\text { firaagustin28@ymail.com }\end{array}$} \\
\hline INFO ARTIKEL & ABSTRAK/ABSTRACK \\
\hline $\begin{array}{l}\text { Histori Artikel :- } \\
\text { Tgl. Masuk : - } \\
\text { Tgl. Diterima : - } \\
\text { Tersedia Online : } 19 \text { desember } \\
2018 \\
\end{array}$ & $\begin{array}{l}\text { Penelitian ini betujuan untuk menguji } \\
\text { pengaruh premium growth ratio, risk based capital } \\
\text { dan hasi investasi terhadap profitabilitas pada } \\
\text { perusahaan asuransi umum yang terdafatar di Bursa }\end{array}$ \\
\hline $\begin{array}{l}\text { Keywords: } \\
\text { Profitabilitas, Return On } \\
\text { Assets (ROA), Premium } \\
\text { Growth Ratio (PGR), Risk } \\
\text { Based Capital (RBC), Hasil } \\
\text { investasi }\end{array}$ & $\begin{array}{l}\text { Efek Indonesia tahun 2010-2014. } \\
\text { Populasi penelitian ini adalah perusahaan } \\
\text { asuransi yang terdaftar di Bursa Efek Indonesia tahun } \\
2010 \text { sampai } 2014 \text {. Teknik pemilihan sampel } \\
\text { menggunakan purposive sampling sehingga } \\
\text { diperoleh sampel yang sesuai kriteria sebanyak } 11 \\
\text { perusahaan. Alat statistik dalam penelitian ini adalah } \\
\text { Eviews } 8.1 \text {. } \\
\text { Hasil penelitian ini menunjukan bahwa secara parsial } \\
\text { premium growth rato dan risk based capital tidak } \\
\text { berpengaruh terhadap return on assets, variabel hasil } \\
\text { investasi berpengaruh terhadap return on assets. } \\
\text { Sedangkan secara simultan variabel premium growth } \\
\text { ratio, risk based capital dan hasil investasi berpengaruh } \\
\text { signifikan terhadap return on assets }\end{array}$ \\
\hline
\end{tabular}

\section{Pendahuluan}

Asuransi merupakan salah satu alternatif untuk mengalihkan dan mengendalikan risiko finansial dari hal-hal yang tidak diinginkan. Usaha perasuransian sebagai salah satu lembaga keuangan menjadi penting perannya karena dari kegiatan perlindungan risiko, perusahaan asuransi menghimpun dana masyarakat dari penerimaan premi. Oleh karena itu, untuk mengatasi semua risiko yang berasal dari para tertanggungnya perusahaan asuransi membutuhkan dana yang cukup besar untuk menutupi semua tanggungan tersebut, sehingga perusahaan bisa tetap mendapatkan keuntungan yang diharapkan.
Kinerja yang baik umumnya dapat dilihat melalui profitabilitas dari suatu laporan keuangan perusahaan. Profitabilitas secara umum didefinisikan sebagai kemampuan bisnis untuk memanfaatkan aset untuk menghasilkan pendapatan dengancara yang efisien. Hal ini digunakan untuk mengidentifikasi apakah sebuah perusahaan bisa menjadi peluang investasi yang berharga (Charumathi, 2012). Profitabilitas merupakan faktor penting dalam manajemen keuangan karena salah satu tujuan manajemen keuangan ialah memaksimalkan kesejahteraan pemegang saham. Salah satu ukuran profitabilitas adalah return on assets (ROA). 
Dalam perusahaan asuransi ROA dapat dipengaruhi oleh rasio keuangan seperti premium growth ratio (PGR) dan risk based capital (RBC). Premium growth ratio (PGR) memberikan gambaran tentang besar kecilnya perubahan perolehan premi netto tahun saat ini dibanding tahun sebelumnya. Hasil dari aktivitas perusahaan akan terefleksi pada perolehaan premi. Semakin besar kepercayaan nasabah terhadap perusahaan, maka akan semakin tinggi perolehan premi yang dikumpulkan. Premi itulah yang kemudian dikelola oleh perusahaan asuransi untuk diinvestasikan dan disiapkan untuk pembayaran klaim (Investor, 2012). Rasio Pertumbuhan Premi atau Premium Growth Ratio (PGR) yang tinggi akan meningkatkan nilai ROA.

Risk based capital (RBC) merupakan rasio untuk mengukur tingkat kecukupan modal pada perusahaan asuransi. Menurut Prawoto (2003), risiko(kerugian) yang menjadi beban perusahaan asuransi/reasuransi harus sebanding dengan modalnya. Semakin tinggi/banyak risiko yang dihadapi maka modalnyapun harus semakin banyak pula. Dengan adanya RBC yang tinggi, makarisiko yang dihadapi akan semakin kecil. Akan tetapi, hal ini membuat perusahaanasuransi umum tidak efisien karena adanya penggunan modal yang diinvestasikan menjadi tidak produktif.Oleh sebab itu.semakin tinggi RBC maka ROA akan semakin rendah.

Dalam Keputusan Menteri Keuangan RI no. 424/KMK.06.2003 pasal 2 dinyatakan bahwa perusahaan asuransi dan perusahaan reasuransi setiap saat wajib memenuhi tingkat solvabilitas paling sedikit $120 \%$ dari risiko kerugian yang muncul sebagai akibat dari devisiasi dalam pengelolaan kekayaan dan kewajiban. Perusahaan asuransi yang tidak memenuhi ketentuan modal menurut PP No 81 Tahun 2008, maka diberi sanksi.
Selanjutnya, pemerintah akan mengisolasi wilayah kerja perusahaan asuransi dalam berbisnis, dimana perusahaan asuransi hanya boleh beroperasi dalam wilayah tertentu saja (kegiatan usahanya dibatasi). Selain itu, regulator juga akan mengenakan sanksi atas produk usaha mereka. Konsekuensinya adalah, perusahaan bermodal minim tersebut dilarang menjual produk mereka.

Rendahnya pertumbuhan laba pada suatu perusahaan menunjukkan tingkat profitabilitas perusahaan juga rendah. Profitabilitas pada hakikatnya merupakan indikator sebuah perusahaan yang bersumber pada kinerja perusahaan tersebut.Selain dari sisi penilaian kesehatan, perusahaan asuransi juga diharapkan memperoleh keuntungan dari kegiatan operasinya sehingga perusahaan dapat berkembang dan maju. Kemampuan perusahaan memperoleh keuntungan (profitabilitas) yang diukur dengan ROA merupakan salah satu faktor penting bagi pemilik dan pemegang saham.

Sumber pendapatan perusahaan asuransi salah satunya adalah dari hasil investasi, karena kegiatan operasional perusahaan asuransi dengan menginvestasikan asset-assetnya agar menghasilkan laba bagi perusahaan. Selain itu hasil investasi juga digunakan untuk menutup beban klaim yang tinggi, maka dari itu perusahaan asuransi sangat mengandalkan hasil investasinya agar perusahaan asuransi tetap bisa beroperasional. Berdasarkan uraian di atas penelitian ini memiliki tujuan untuk menguji pengaruh premium growth ratio, risk based capital dan hasi investasi terhadap profitabilitas.

Menurut Grand Theory yang dikemukakan oleh Keown (2005), semakin tinggi risiko, semakin tinggi return yang akan diterima begitu pula sebaliknya, penelitian ini menduga bahwa Premium 
Growth Ratio (PGR) berpengaruh terhadap Return On Assets (ROA) pada perusahaan asuransi. Berdasarkan Peraturan Menteri Keuangan Republik Indonesia Nomor.53/PMK.010/2012 tentang Kesehatan Keuangan Perusahaan Asuransi dan Perusahaan Reasuransi, setiap perusahaan asuransi wajib memiliki Risk Based Capital (RBC) minimal 120\%. RBC diarahkan untuk melihat tingkat keamanan yang dapat diberikan oleh perusahaan kepada pemegang polis sehingga dapat memberikan kepercayaan yang tinggi kepada masyarakat terhadap perusahaan asuransi, RBC yang tinggi menunjukkan tingkat kecukupan modal yang tinggi bagi perusahaan asuransi dalam memenuhi kewajibankewajibannya. Penelitian ini menduga bahwa Risk Based Capital (RBC) berpengaruh terhadap Return On Assets (ROA) pada perusahaan asuransi. Hasil investasi yang tinggi akan menambah jumlah profit yang diperoleh perusahaan sehingga jika perusahaan mendapatkan laba maka profitabiltasnya akan naik dengan begitu modal perusahaan akan bertambah sehingga jumlah asset perusahaan juga akan bertambah penelitian ini menduga bahwa Investasi berpengaruh terhadap Return On Assets (ROA) pada perusahaan asuransi. Dari penjelasan teoritis di atas maka peneliti menduga bahwa Premium Growth Ratio (PGR), Risk Based Capital (RBC) dan hasil investasi berpengaruh terhadap Return On Assets (ROA) pada perusahaan asuransi.

Untuk membuktikan hipotesis berikut maka penelitian ini menggunakan metode regresi data panel dengan sumber data sekunder dalam bentuk dokumentasi yang dipublikasikan oleh Bursa Efek Indonesia (www.idx.co.id) untuk Laporan Keuangan Perusahaan Asuransi.

Hasil penelitian menunjukan bahwa dari empat hipotesis yang diajukan terdapat dua hipotesis yang ditolak.
Premium growth ratio tidak berpengaruh terhadap Retun On Assets. Risk based capital tidak berpengaruh terhadap Return On Assets. Investasi berpengaruh terhadap Return On Assets. Premium Growth Ratio, Risk Based Capital dan hasil investasi secara simultan berpengaruh terhadap Return On Assets .

Kontribusi yang dapat diberikan dari penelitian ini adalah dapat dijadikan sebagai sumber informasi khususnya bagi perusahaan asuransi untuk lebih pintar dalam berinvestasi agar dapat meningkatkan profitabilitas perusahaan.

\section{Literatur Review dan Hipotesis}

Profitabilitas merupakan salah satu tujuan perusahaan. Setiap perusahaan mengharapkan laba yang optimum dari tahun ke tahun. Profitabilitas sendiri merupakan selisih antara pendapatan yang diperoleh dengan biaya yang dikeluarkan oleh perusahaan selama periode tertentu. Profitabilitas merupakan salah satu sumber dalam pengambilan keputusan bagi berbagai pihak, baik pihak internal maupun eksternal perusahaan. Salah satu rasio profitabilitas yaitu return on assets.

Faktor-faktor yang mempengaruhi return on assets diantaranya yaitu premium growth capital, risk based capital, dan hasil investasi. Premi salah satu sumber pendapatan dari perusahaan asuransi, pendapatan yang terkumpul atas premi yang dibayarkan oleh para nasabah di investasikan oleh perusahaan untuk mendapatkan laba dari hasil investasi tersebut. Hasil investasi yang baik akan membuat profitabilitas perusahaan meningkat sehingga model perusahaan akan bertambah, ketika modal perusahaan maka jumlah asset perusahaan akan bertambah. Sehingga semakin besar pertumbuhan premi maka memungkinkan perusahaan untuk 
mendapatkan return on assets yang besar pula.

Risk based capital sebagai pengukur dari rasio solvabilitas untuk perusahaan asuransi. Risk based capital diartikan sebagai jumlah modal yang diperlukan untuk meyakinkan pihak-pihak terkait tentang kekuatan modal dalam perusahaan. Risk based capital diharapkan menjadi cermin dari kemampuan perusahaan dalam memperoleh profitabilitas. Tingkat risk based capital juga mencerminkan komposisi modal dan riskobisnis yang dikelolanya, selain itu kemampuan mempertahankan tingakat risk based capital menunjukan kemampuan perusahaan asuransi untuk bersaing.

Hasil investasi pada dasarnya adalah penghasilan dari portofolio investasi aktiva perusahaan asuransi. Hasil investasi adalah hasil operasi perusahaan asuransi maka terkumpul sejumlah uang untuk dibagi hasilkan kepada peserta asuransi. Hasil investasi disajikan setelah pendapatan investasi dikurangi dengan beban investasi terkait langsung. Perusahaan yang menginvestasikan assetasset nya dengan tepat akan mendapatkan hasil investasi yang tinggi sehingga perusahaan mampu menambah jumlah asset untuk diinvestasikan kembali, dengan demikian maka profitabilitas yang diukur dengan return on assets akan tinggi.

Hipotesis dalam penelitian ini adalah prediksi awal kesimpulan sementara hubungan antara variabel independen dengan variabel dependen sebelum dilakukan penelitian dan harus dibuktikan melalui penelitian, maka hipotesis yang dapat diajukan dalam penelitian ini adalah sebagai berikut:

1. Pengaruh Premium Growth Capital (PGR) terhadap Return On Assets (ROA)
Menurut Soeisno Djojosoedarso (2003:127 dalam Dhaniati:2011): "premi asuransi adalah pembayaran daritertanggung kepada penanggung, sebagai imbalan jasa atas pengalihan risiko kepada penanggung". Penerimaan premi adalah jumlah pendapatan premi dari penjualan polis asuransiyang biasanya diukur dalam periode satu tahun. Premi tersebut lalu dialokasikan untuk cadangan teknis guna pembayaran klaim dan investasi untuk memberikan keuntungan pada perusahaan. Selain itu, premi yang tinggi memuat unsur penerimaan risiko yang tinggi pula. Berdasarkan Grand Theory yang dikemukakan oleh Keown (2005), semakin tinggi risiko, semakin tinggi return yang akan diterima, begitu pula sebaliknya. Pertumbuhan premi yang tinggi akan menambah pendapatan perusahaan asuransi, maka pengalokasian premi untuk investasi akan semakin meningkat sehingga jika investasi bisa dilakukan dengan baik dan efisien akan menghasilkan pendapatan yang bersumber dari hasil investasi semakin besar. Jika pendapatan perusahaan meningkat maka laba yang diperoleh akan tinggi sehingga jika perusahaan itu mendapatkan laba maka akan menambah jumlah modal yang diperoleh perusahaan, dengan begitu jumlah asset yang dimiliki perusahaan akan bertambah. Oleh sebab itu, semakin tinggi Premium Growth Ratio (PGR) maka ROA perusahaan semakin tinggi. Berdasarkan penjelasan teoritis tersebut di atas, maka dapat 
diajukan Hipotesis 1 sebagai berikut :

$\mathrm{H} 1$ : Premium Growth Ratio (PGR) berpengaruh terhadap Return On Assets (ROA) pada perusahaan asuransi.

2. Pengaruh Risk Based Capital (RBC) Terhadap Return On Assets (ROA)

Risk based capital adalah metode pengukuran batas tingkat solvabilitas yang disyaratkan dalam undang-undang dalam mengukur tingkat kesehatan keuangan sebiah perusahaan asuransi untuk memastikan pemenuhan kewajiban asuransi dan reasuransi dengan mengetahui besarnya kebutuhan modal dan perusahaan sesuai dengan tingkat resiko yang dihadapi perusahaan dalam mengelola kekayaan dan kewajibannya (Kirmizi hal 39:2011). Peraturan pemerintah mengenai batas tingkat solvabilitas perusahan asuransi menyebabkan perusahaan asuransi sebagai pengelola harus dapat melakukan serangkaian cara agar dapat memenuhi klaim. Sebab jika RBC kurang, maka pengelola perusahaana asuransi wajib memberikan tambahan modal untuk menutupi kekurangan rasio RBC.Perusahaan juga dilarang membagikan deviden atau memberikan imbalan dalam bentuk apapun kepada pemagang saham dan sangat berisiko perusahaan tersebut ditutup jika tida ditingkatkan kesehatan keuanganya. Kemudian, efek samping diterapkannya RBC bagi perusahaan asuransi adalah dari seluruh asset yang dimiliki oleh perusahaan asuransi, sebagian besar tersebut harus disisihkan untuk memnuhi persyaratan asset yang diperkenankan.Hal ini tentunya dapat mempengaruhi tujuan perusahaan untuk mendapatkan laba (profitabilitas) yang diharapkan. Profitabilitas hakikatnya merupakan indikator sebuah perusahaan yang merepresentasikan efisiensi kinerja perusahaan tersebut.Selain dari sisi penilaian kesehatan, perusahaan asuransi juga diharapkan memperoleh keuntungan dari kegiatan operasinya sehingga perusahaan dapat berkembang. Jika perusahaan memutuskan untuk memenuhi tingkat solvabilitas tercapai dalam jumlah besar kemungkinan rasio $\mathrm{RBC}$ terjaga namun kesempatan memperoleh laba yang besar akan menurun sehingga berdampak pada penurunan profitabilitas. Penelitian Kirmizi dan Agus (2011), Supriyono (2013) serta Ningrum (2014) menyatakan bahwa RBC memiliki pengaruh negatif terhadap profitabilitas (ROE). Berdasarkan penjelasan teoritis tersebut di atas, maka dapat diajukanHipotesis 2 sebagai berikut:

H2: Risk Based Capital (RBC) berpengaruh terhadap Return On Assets (ROA) pada perusahaan asuransi.

3. Pengaruh Hasil Investasi Terhadap Return On Assets (ROA)

Investasi merupakan penempatan seumlah dana pada saat ini dengan harapan untuk memperoleh keuntungan di masa mendatang (Abdul Halim: 2005). Sedangkan hasil investasi pada dasarnya adalah penghasilan dari portofolio investasi aktiva perusahaan asuransi. Hasil investasi adalah 
hasil operasi perusahaan asuransi maka terkumpul sejumlah uang untuk dibagi hasilkan kepada peserta asuransi.Hasil investasi disajikan setelah pendapatan investasi dikurangi dengan beban investasi terkait langsung. Premi yang terkumpul pada setiap perusahaan asuransi jiwa mencapai jumlah milyaran rupiah. Oleh karena itu menjadi sangat penting bagi perusahaan asuransi untuk melakukan investasi atas aset-aset yang ada untuk mencukupi kebutuhan akan dana yang dikelola. Sebagian besar perusahaan asuransi mengandalkan hasil investasinya untuk menutupi kekurangan akan tarif premi yang diberikan kepada tertanggung. Perusahaan asuransi melakukan strategi investasinya melalui berbagai instrumen portofolio yang dianggap dapat memberikan return on assets/return on investment yang paling baik dan tetap tunduk pada aturan serta batasan yang telah ditetapkan dalam Keputusan Menteri Keuangan Republik Indonesia Nomor 424 tahun 2003 tentang kesehatan keuangan perusahaan asuransi dan perusahaan reasuransi. Perusahaan asuransi harus menyeimbangkan strategi investasinya dengan regulasi yang telah ada. Hasil investasi yang tinggi akan menambah jumlah profit yang diperoleh perusahaan sehingga jika perusahaan mendapatkan laba maka profitabiltasnya akan naik. Dengan begitu modal perusahaan akan bertambah sehingga jumlah asset perusahaan juga akan bertambah. Berdasarkan penjelasan teoritis tersebut di atas, maka dapat diajukan Hipotesis 3 sebagai berikut:

H3: Hasil Investasi berpengaruh terhadap Return On Assets (ROA) pada perusahaan asuransi.

4. Pengaruh Premium Growth Ratio $(P G R)$, Risk Based Capital (RBC) Dan Hasil Investasi Terhadap Return On Assets (ROA)

Semua variabel dependen premium growth ratio (PGR), risk based capital (RBC) dan hasil investasi secara bersama berpengaruh terhadap variabel independen return on assets (ROA). Berdasarkan penjelasan teoritis tersebut di atas, maka dapat diajukan Hipotesis 4 sebagai berikut:

H4: Premium Growth Ratio (PGR), Risk Based Capital (RBC) dan hasil investasi berpengaruh terhadap Return On Assets (ROA) pada perusahaan asuransi.

\section{Metode Penelitian}

Penelitian ini merupakan penelitian kuantitatif dan sumber data yang digunakan dalam penelitian ini adalah data skunder dalam bentuk dokume

ntasi

yang dipublik asikan

oleh

Bursa

Efek Indonesi

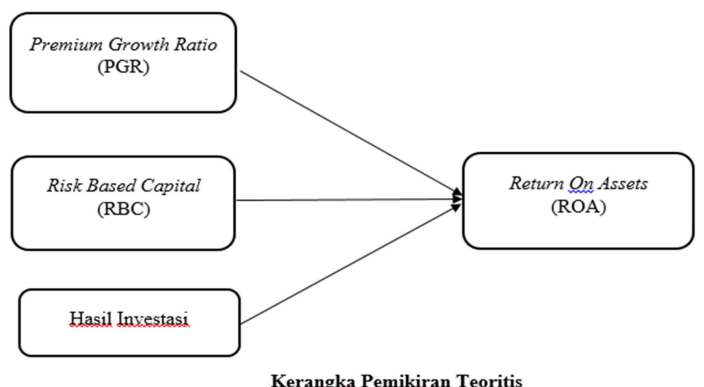
a (www.idx.co.id) untuk Laporan Keuangan Perusahaan Asuransi. Populasi yang diambil penulis dalam penelitian ini adalah seluruh perusahaan asuransi yang terdaftar di Bursa Efek Indonesia.

Tabel 
Perusahaan Asuransi Umum yang Terdaftar di BEI

\begin{tabular}{|l|l|l|}
\hline No & \multicolumn{1}{|c|}{$\begin{array}{c}\text { Kode } \\
\text { Perusahaan }\end{array}$} & \multicolumn{1}{|c|}{ Nama Perusahaan } \\
\hline 1 & ABDA & $\begin{array}{l}\text { Asuransi Bina Dana } \\
\text { Arta }\end{array}$ \\
\hline 2 & AHAP & $\begin{array}{l}\text { Asuransi Harta Aman } \\
\text { Pratama }\end{array}$ \\
\hline 3 & AMAG & $\begin{array}{l}\text { Asuransi Multi Artha } \\
\text { Pratama }\end{array}$ \\
\hline 4 & ASBI & Asuransi Bintang \\
\hline 5 & ASDM & Asuransi Dayin Mitra \\
\hline 6 & ASJT & Asuransi Jaya Tania \\
\hline 7 & ASRM & Asuransi Ramayana \\
\hline 8 & LPGI & $\begin{array}{l}\text { Lippo General } \\
\text { Insurance }\end{array}$ \\
\hline 9 & MREI & $\begin{array}{l}\text { Maskapai Reasuransi } \\
\text { Indonesia }\end{array}$ \\
\hline 10 & PNN & Panin Insurance \\
\hline 11 & PNLF & Panin Financial \\
\hline 12 & VINS & Victoria Insurance \\
\hline
\end{tabular}

Penelitian ini menggunakan purposive sampling yakni teknik penentuan sampel dengan kriteria tertentu. Kriteria sampel dalam penelitian ini adalah perusahaan asuransi yang menyajikan laporan keuangan tahun 2010-2014 yang terdaftar di BEI dan yang menerbitkan laporan keuangan tahun 2012-2014.

Dimana :

Premium Growth Ratio (PGR) = Variabel Independen $\mathrm{X}_{1}$

Risk Based Capital (RBC) = Variabel

Independen $\mathrm{X}_{2}$

Hasil Investasi = Variabel

Independen $\mathrm{X}_{3}$

Return On Assets (ROA) = Variabel

Dependen $Y$

Premium Growth Ratio (PGR) memberikan gambaran tentang besar kecilnya perubahan perolehan premi neto tahun saat dibanding tahun sebelumnya.
Menggunakan skala rasio dengan indikator perhitungan sebagai berikut :

$P G R$

$=\frac{\text { perubahan premi netto }}{\text { premi netto tahun sebelumnya }} \times 100 \%$

Risk Based Capital (RBC)

merupakan rasio kecukupan model terhadap resiko yang ditanggung dan menjadi salah satu indikator utama dalam menilai kesehatan perusahaan asuransi. Khususnya yang terkait dengan solvabilitas atau kemampuan perusahaan dalam memenuhi semua kewajibannya. Menggunakan skala rasio dengan indikator perhitungan sebagai berikut :

$R B C$

$=\frac{\text { aseets yg diperkenankan }- \text { liabilitas yg diperkenankan }}{\text { batas minimun tingkat solvabilitas }} \times 100 \%$ Hasil Investasi adalah hasil operasi perusahaan asuransi maka terkumpul sejumlah uang untuk dibagi hasilkan kepada peserta asuransi. Menggunakan skala rasio dengan indikator perhitungan sebagai berikut :

Hasil Investasi

$$
\begin{aligned}
& \text { - Pendapatan investasi } \\
& \text { - beban investasi }
\end{aligned}
$$

Return On Assets (ROA) adalah rasio yang menggambarkan kemampuan bank dalam mengelola dana yang diinvestasikan dalam keseluruhan aktiva yang menghasilkan keuntungan. Menggunakan skala rasio dengan indikator perhitungan sebagai berikut :

ROA $=\frac{\text { Laba sebelum pajak }}{\text { Total aktiva }} \times 100 \%$

\section{Hasil Penelitian}

Analisis Deskriptif Statistik

Statistik deskriptif disajikan pada tabel berikut ini :

Tabel Deskriptif Statistik

\begin{tabular}{|c|c|c|c|c|c|c|c|c|}
\hline $\begin{array}{c}\text { Variabe } \\
\text { I }\end{array}$ & Mean & $\begin{array}{c}\text { Medi } \\
\text { an }\end{array}$ & Max & Min & $\begin{array}{c}\text { Stan } \\
\text { dar } \\
\text { Devia } \\
\text { si }\end{array}$ & $\begin{array}{c}\text { Jarque } \\
\text { Bera }\end{array}$ & $\begin{array}{c}\text { Probab Observ } \\
\text { ility }\end{array}$ & ations \\
\hline
\end{tabular}




\begin{tabular}{|c|c|c|c|c|c|c|c|c|}
\hline $\begin{array}{c}\text { Variabe } \\
1\end{array}$ & Mean & $\begin{array}{c}\text { Medi } \\
\text { an }\end{array}$ & Max & Min & \begin{tabular}{|c|} 
Stan \\
dar \\
Devia \\
si \\
\end{tabular} & $\begin{array}{c}\text { Jarque } \\
\text { Bera }\end{array}$ & $\begin{array}{c}\text { Probab } \\
\text { ility }\end{array}$ & $\begin{array}{l}\text { Observ } \\
\text { ations }\end{array}$ \\
\hline \begin{tabular}{|l} 
Premiu \\
$m$ \\
Growth \\
Ratio \\
\end{tabular} & $\begin{array}{c}0,225 \\
0\end{array}$ & $\begin{array}{c}0,213 \\
1\end{array}$ & 0,7973 & $\begin{array}{c}- \\
0,1308\end{array}$ & \begin{tabular}{|c|}
0,186 \\
5
\end{tabular} & 6,0871 & 0,0476 & 55 \\
\hline \begin{tabular}{|l|} 
Risk \\
Based \\
Capital
\end{tabular} & $\begin{array}{c}3,929 \\
5\end{array}$ & \begin{tabular}{|c|}
2,271 \\
1
\end{tabular} & $\begin{array}{c}24,820 \\
0\end{array}$ & 1,3075 & & $\begin{array}{c}323,953 \\
4\end{array}$ & 0,000 & 55 \\
\hline \begin{tabular}{|l} 
Hasil \\
Investas \\
i
\end{tabular} & $\begin{array}{l}9747 \\
5513\end{array}$ & $\begin{array}{l}2805 \\
6744\end{array}$ & $\begin{array}{c}1,77 \mathrm{E}+ \\
09\end{array}$ & $\begin{array}{c}31444 \\
40\end{array}$ & $\begin{array}{r}2,29 \mathrm{E} \\
+08\end{array}$ & 536,440 & 0,000 & 55 \\
\hline \begin{tabular}{|l} 
Return \\
On \\
Assets \\
(ROA)
\end{tabular} & $\begin{array}{c}0,063 \\
8\end{array}$ & $\begin{array}{c}0,065 \\
8\end{array}$ & 0,1173 & 0,0001 & $\mid \begin{array}{c}0,028 \\
1\end{array}$ & 1,9920 & 0,3693 & 55 \\
\hline
\end{tabular}

Jumlah data perusahaan ditunjukan oleh nilai observation yaitu 55 data. Nilai mean, maximum, dan minimum menunjukan data atas nilai rata-rata tertinggi dan terendah setiap variabel. Adapun ukuran sebaran seputar rata-rata setiap variabel diperlihatkan oleh nilai standar deviasi.

\section{Analisis Uji Regresi Berganda}

$$
\text { Untuk Menguji kebenaran }
$$
hipotesis dilakukan dengan menggunakan uji regresi berganda. Penelitian ini memiliki 3 variabel bebas, dan 1 vriabel dependen. Variabel indenpenden tersebut diantaranya Premium Growth Ratio $\left(\mathrm{X}_{1}\right)$, Risk Based Capital $\left(\mathrm{X}_{2}\right)$, dan Hasil Investasi $\left(\mathrm{X}_{3}\right)$. Kemudian variabel dependen yaitu Return On Assets (Y). Alat statistik yang digunakan dalam penelitian ini sebagai alat bantu untuk melakukan uji regresi berganda yaitu Eviews 8.1. Hasil analisis model regresi dijabarkan sebagai berikut:

Tabel Regresi Berganda

\begin{tabular}{|l|cr|}
\hline \multicolumn{1}{|c|}{ Variabel } & Koefisien & Prob \\
\hline Constans & 0,056639 & 0,0000 \\
PGR & 0,020117 & 0,1192 \\
RBC & $-0,000930$ & 0,3416 \\
Hasil & $6,42 \mathrm{E}-11$ & 0,0013 \\
Investasi & \\
\hline \multicolumn{2}{|c|}{} \\
\hline R-squared & & 0,273972 \\
Adjusted R- & & 0,231264 \\
\hline
\end{tabular}

\begin{tabular}{|l|l|}
\hline $\begin{array}{l}\text { squared } \\
\text { S.E of } \\
\text { regression }\end{array}$ & 0,015394 \\
$\begin{array}{l}\text { F-statistic } \\
\text { Prob (F- } \\
\text { tatistic) }\end{array}$ & 6,415065 \\
\hline
\end{tabular}

Hasil regresi pada tabel di atas, merupakan output yang diperoleh dari model regresi data panel random effect (RE). Model regresi RE terpilih menjadi model terbaik untuk dipakai dalam analisis berganda setelah melalui beberapa tahapan proses. Dari tabel di atas, dapat diketahui nilai konstanta dan koefisien regresi sehingga dapat disusun persamaan regresi berganda linear sebagai berikut:

$$
\begin{gathered}
Y=0,056639+0,020117 X_{1}- \\
0,000930 X_{2}+6,42 E-11 X_{3}+e
\end{gathered}
$$

Keterangan:

$\mathrm{Y}=$ Return On Assets

$\mathrm{X}_{1}=$ Premium Growth Ratio

$\mathrm{X}_{2}=$ Risk Based Capital

$\mathrm{X}_{3}=$ Hasil Investasi

Untuk mengetahui ketepatan fungsi regresi model $\mathrm{FE}$ dalam menaksirkan nilai actual maka dilakukan pengujian Goodness of fit. Secara statistik, dapat diukur dengan nilai statistik $F$, nilai koefisien determinasi, dan nilai statistik $t$, hasil analisis Goodness of fit model $\mathrm{FE}$ diuraikan sebagai berikut:

1. Uji statistik $t$

Kriteria Uji t yaitu apabila nilai prob menunjukan tingkat signifikansi kurang dari $\alpha(\alpha=1 \%, \alpha=5 \%$, atau $\alpha=10 \%)$ maka terdapat pengaruh yang signifikan antara satu variabel independen terhadap variabel dependen. Berikut adalah hasil uji t penelitian ini:

Tabel Uji Signifikan t

\begin{tabular}{|c|c|c|c|c|}
\hline $\begin{array}{c}\text { Variab } \\
\text { el }\end{array}$ & $\begin{array}{c}\text { Koefisie } \\
\mathbf{n}\end{array}$ & Prob & $\begin{array}{c}\text { Keterang } \\
\text { an }\end{array}$ & $\begin{array}{c}\text { Keputusa } \\
\mathbf{n} \\
\text { Hipotesis }\end{array}$ \\
\hline PGR & 0,02011 & 0,119 & Tidak & Ditolak \\
\hline
\end{tabular}




\begin{tabular}{|l|c|c|l|l|}
\hline & 7 & 2 & signifikan & \\
\hline RBC & - & 0,341 & Tidak & Ditolak \\
& 0,00093 & 6 & signifikan & \\
0 & & & \\
\hline $\begin{array}{l}\text { Hasil } \\
\text { investa } \\
\text { si }\end{array}$ & $\begin{array}{c}6,42 \mathrm{E}- \\
11\end{array}$ & $\begin{array}{c}0,001 \\
3\end{array}$ & Signifikan & Diterima \\
\hline \multicolumn{4}{|l|}{ Signifikan pada level 5\% } & \\
\hline
\end{tabular}

Berdasarkan tabel di atas, pengujian hipotesis dalam penelitian ini dapat dijabarkan sebagai berikut:

a. Premium Growth Ratio memiliki nilai koefisien 0,020117 dan prob.0,1192 (prob> $\alpha$ ), artinya variabel premium growth ratio tidak berpengaruh terhadap return on assets.

b. Risk based capital memiliki nilai koefisien $-0,000930$ dan prob 0,3416 (prob> $\alpha$ ), artinya variabel Risk Based Capital tidak berpengaruh terhadap return on assets

c. Hasil investasi memiliki nilai koefisien 6,42E-11 dan prob. $0,0013$ (prob< $\alpha)$, artinya variabel hasil investasi berpengaruh signifikan terhadap return on assets.

\section{Uji statistik $F$}

Tabel Uji Signifikasi F

\begin{tabular}{|c|c|}
\hline \multicolumn{2}{|c|}{ MODEL RE } \\
\hline F- statistic & 6,415065 \\
\hline Prob (F-statistic) & 0,000903 \\
\hline
\end{tabular}

menunjukan bahwa uji $\mathrm{F}$ pada model regresi adalah signifikan. $\mathrm{Hal}$ ini ditunjukan oleh nilai Prob (F-statistic) yang lebih kecil dari $\alpha$, yaitu 0,000903 . Artinya bahwa ketiga variabel independen yaitu Premium Growth Ratio, Risk Based Capital, Hasil investasi secara bersamasama berpengaruh terhadap Return On Assets.

3. Uji Koefisien Determinasi $\left(R^{2}\right)$
Tabel Uji Koefisien Determinasi $\left(\mathbf{R}^{2}\right)$

\begin{tabular}{|l|l|}
\hline \multicolumn{2}{|c|}{ MODEL RE } \\
\hline R-squared & 0,273972 \\
Adjusted R-squared & 0,231264 \\
\hline
\end{tabular}

Pada tabel diatas, menunjukan nilai $R^{2}$ sebesar 0,273972 artinya variabel Return On Assets mampu dijelaskan oleh variabel Premium Growth Ratio, Risk Based Capital, dan Hasil investasi sebesar 0,273972 atau $27,39 \%$ sedangkan selebihnya dijelaskan oleh faktor lain yang tidak diteliti dalam penelitian ini.

\section{Pembahasan}

Hipotesis 1: Pengaruh Premium Growth Ratio terhadap Return On Assets

Hasil uji t atas PGR pada tabel 4.14 adalah tidak signifikan karena memiliki nilai koefisien 0,020117 dan prob. 0,1192 (Prob>), artinya variabel premium growth ratio tidak berpengaruh terhadap return on assets, dengan demikian $\mathrm{H} 1$ ditolak. Tidak berpengaruhnya pertumbuhan premi terhadap return on assets perusahaan asuransi dapat disebabkan oleh beberapa faktor. Salah satu faktor tersebut adalah besarnya jumlah klaim yang terjadi, peningkatan jumlah premi yang diperoleh tidak akan berarti banyak jika diikuti dengan peningkatan jumlah klaim.

Hal ini karena klaim merupakan beban perusahaan sehingga meskipun perusahaan mencatatkan peningkatan premi namun disisi lain juga menerima klaim yang cukup besar maka penerimaantersebut akan dialihkan untuk membiayai klaim yang terjadi. Oleh karena itu, ketika pertumbuhan premi perusahaan itu besar tetapi tidak berpengaruh terhadap jumlah asset yang dimilikinya.

Hipotesis 2: Pengaruh Risk Based Capital terhadap Return On Assets

Hasil uji t atas risk based capital pada Tabel 4.14 adalah tidak signifikan 
karena memiliki nilai koefisien $-0,000930$ dan probability0,3416 (Prob $>\alpha$ ), artinya risk based capital tidak berpengaruh terhadap return on assets, dengan demikian hipotesis 2 ditolak. Kemampuan perusahaan asuransi dalam memenuhitingkat risk based capital tidak berpengaruh secara langsung terhadap pencapaian profitabilitas perusahaan asuransi.

Pencapaian tingkat risk based capital yang disyaratkan pemerintah hanya memberikan informasi mengenai kesehatan kondisi keuangan perusahaan terhadap memenuhi kewajibannya dan pengelolaan resiko yang akan ditanggung. Oleh sebab itu, risk based capital menjadi alat ukur yang digunakan oleh para nasabah dan investor untuk memperkirakan kesehatan keuangan perusahaan asuransi bukan sebagai indikator profitabilitas yang akandicapai. Penelitian ini sejalan dengan penelitian Imtikhanah dkk (2013) yang menunjukkan bahwa risk based capitaltidak berpengaruh terhadap profitabilitas yang diukur dengan return on assets.

\section{Hipotesis 3: Pengaruh Hasil Investasi terhadap Return On Assets}

Hasil uji t atas hasil investasi pada Tabel 4.14 adalah signifikan karena nilai probability lebih kecil dari (5\%). Oleh sebab itu, hasil ini menerima hipotesis H3 yang menyatakan bahwa hasil investasi berpengaruh terhadap return on assets. Nilai koefisien hasil investasi sebesar 6.42E-11 mencerminkan bahwa hasil investasi memiliki pengaruh positif terhadap return on assets. Dengan hasil investasi yang diperoleh perusahaan bisa menambah jumlah assetsnya baik untuk operasional maupun untuk diinvestasikan lagi.

Sehingga dapat disimpulkan bahwa variabel hasil investasi berpengaruh signifikan terhadap return on assets perusahaan asuransi. Hal ini menunjukkan bahwa hasil investasi secara parsial bermanfaat dalam memprediksikan return on asssets perusahaan asuransi, yang berarti jika nilai hasil investasi naik maka akan meningkatkan return on assets yang diperoleh perusahaan. Hasil penelitian ini sejalan dengan penelitian yang dilakukan oleh Ali fikri (2009), bahwa rasio hasil investasi berpengaruh terhadap laba.

Hipotesis 4: Pengaruh Premium Growth Ratio, Risk Based Capital dan Hasil Investasi terhadap Return On Assets secara simultan

Berdasarkan Tabel $\quad 4.15$ menunjukkan bahwa hasil uji $F$ pada model regresi adalah signifikan. Hal ini ditunjukkan oleh nilai Prob (F-statistic) yang lebih kecil dari, yaitu 0,001034. Artinya bahwa ketiga variabel independen yaitu premium growth ratio, risk based capital dan hasil investasi secara bersamasama berpengaruh terhadap return on assets. Dengan demikian hasil penelitian dapat disimpulkan bahwa keragaman dari retun on assets $(\mathrm{Y})$ ditentukan oleh adanya prem

\section{Kesimpulan}

Berdasarkan hasil penelitian mengenai pengaruh premium growth ratio, risk based capital dan hasil investasi terhadap profitabilitas pada perusahaan asuransi umum yang terdaftar di Bursa Efek Indonesia tahun 2010-2014 dapat diambil kesimpulan bahwa Premium growth ratio tidak berpengaruh terhadap retun on assets hal ini dapat dilihat dari hasil uji t memiliki nilai probability lebih besar dari a yaitu 0,1192. Hal ini dikarenakan dengan bertumbuhnya premi tidak berarti profitabilitas perusahaan itu bertambah karena salah satunya adalah meningkatnya pertumbuhan klaim yang terjadi sehingga beban yang dikeluarkan oleh perusahaan lebih besar dari pada pendapatan yang diperoleh dari premi itu sendiri. Risk based capital tidak 
berpengaruh terhadap return on assets hal ini dapat dilihat dari hasil uji t memiliki nilai probability lebih besar dari $\alpha$ yaitu 0,3416 . Kemampuan perusahaan asuransi dalam memenuhi tingkat risk based capital tidak berpengaruh secara langsung terhadap pencapaian profitabilitas perusahaan asuransi. Pencapaian tingkat risk based capital yang disyaratkan pemerintah hanya memberikan informasi mengenai kesehatan kondisi keuangan perusahaan terhadap memenuhi kewajibannya dan pengelolaan resiko yang akan ditanggung.

Hasil investasi berpengaruh terhadap return on assets hal ini dapat dilihat dari hasil uji $t$ memiliki nilai probability lebih kecil dari $\alpha$ yaitu 0,0013 . $\mathrm{Hal}$ ini menunjukkan bahwa hasil investasi secara parsial bermanfaat dalam memprediksikan return on asssets perusahaan asuransi, yang berarti jika nilai hasil investasi naik maka akan meningkatkan return on assets yang diperoleh perusahaan. Hasil investasi yang tinggi memungkinkan perusahaan untuk meningkatkan jumlah assetnya untuk bias diinvestasikan. Premium growth ratio, risk based capital dan hasil investasi secara simultan berpengaruh terhadap return on assets, hal ini dapat dilihat hasil uji $\mathrm{F}$ yang menunjukkan nilai probability lebih kecil dari a yaitu 0,001034. Artinya bahwa return on assets perusahaan asuransi dapat dipengaruhi oleh ketiga variable independen tersebut.

\section{Saran}

Bagi peneliti selanjutnya disarnakan untuk menambah periode penelitian atau objek penelitian menggunakan perusahaan asuransi syariah dan mempersempit sampel agar lebih berfokus pada masalah perusahaan serta menambahkan variabel-variabel independen lain dalam penelitian yang mempengaruhi profitabilitas dan menggunakan rasio lain dalam mengukur profitabilitas, misalnya return on investment atau return on equity. Agar penelitian serupa ke depannya dapat meminimalisir kekurangan yang terjadi dalam penelitian ini dan dapat mengidentifikasi lebih detail dibandingkan penelitian ini.

Bagi perusahaan disarankan agar lebih pintar dalam berinvestasi agar hasil investasi yang didapat semakin tinggi sehingga meningkatkan profitabilitas perusahaan.

\section{DAFTAR PUSTAKA}

Ajija, Schochrul R dan Setianto, Rahmat H. 2011. Cara Cerdas Menguasi Eviews. Jakarta. Salemba Empat.

Almajali, A.Y.; Alamro, S.A. \& Al-Soub, Y.Z. (2012). Factors Affecting the Financial Performance of Jordanian Insurance Companies Listed at Amman Stock Exchange, Journal of Management Research, 4(2): 266-289.

Amrin, Abdullah. 2009. Bisnis, Ekonomi, Asuransi dan Akuntansi Keuangan Syariah. Jakarta: PT Grasindo.

Darmawi, Herman. 2006. Manajemen Asuransi. Jakarta: PT Bumi Aksara. Dhaniati, Rina. 2011. Pengaruh RBC, Rasio Underwriting, Rasio Hasil Investasi,

Rasio Penerimaan Premi, dan Rasio Beban Klaim Terhadap Laba Perusahaan Asuransi (Studi Kasus Pada 9 Perusahaan Asuransi Kerugian Yang Terdaftar Di Bursa Efek Indonesia). Jurnal Akuntansi, Universitas Gunadarma. 
Eskananda, Mahyus. 2014. Analisis Ekonometrika Data Panel. Jakarta : Mitra Wacana Media.

Fadhullah, Arief. 2014. Pengaruh Pendapatan Premi dan Hasil Investasi Terhadap Cadangan Dana Tabarru' (Studi Pada PT. Sinarmas Syariah). Skripsi. Jakarta: Fakultas Syariah dan Hukum, UIN Syarif Hidayatullah.

Fahmi, Irham. 2012. Analisis Kinerja Keuangan. Bandung: Alfabeta.

Fitriyani. 2014. Pengaruh Risk Based Capital Terhadap Profitabilitas Pada Perusahaan Asuransi Syariah AXA Mandiri Periode 2011-2013. Skripsi. Universitas Islam Bandung

Ghofar, ABD. 2012. Pengaruh Premi, Klaim, Investasi dan Profitabilitas Terhadap Pertumbuhan Asset Pada Perusahaan Asuransi Syariah Di Indonesia. Skripsi. Yogyakarta: Fakultas Syari'ah dan Hukum, Universitas Negeri Sunan Kalijaga.

Ghozali, Imam dan Ratmono Dwi. 2013. Aplikasi Analisis Multivariat dan Ekonometrika Teori, Konsep, dan Aplikasi dengan Eviews 8. Semarang. Badan Penerbitan Universitas Dipeonegoro.

Hanafi, Mahmud M dan Abdul Halim. 2005. Analisi Laporan Keuangan.

Yogyakarta: Unit Penerbit dan Percetakan AMP-YKPN.

Kasmir. 2013. Analisis Laporan Keuangan. Jakarta: Rajawali Pers.

Imtikhanah, Sobrotul; Yonai \& Neng Teresnawati. 2013. Pengaruh Pertumbuhan Modal dan Risk Based Capital (RBC) terhadap Profitabilitas Perusahaan Asuransi Syariah di Indonesia. Majalah Neraca. 9 (2): 65-86.
Khotimah, Husnul. 2014. Pengaruh Premi, Klaim, Hasil Investasi dan Underwriting Terhadap Laba Perusahaan Asuransi Syariah Pada PT. Asuransi Kerugian Sinarmas Cabang Syariah. Skripsi. Jakarta: Fakultas Syariah dan Hukum, Universitas Islam Negeri.

Kirmizi, dan Susi Surya Agus. (2011). Pengaruh Pertumbuhan Modal dan Asset Terhadap Rasio Risk Based Capital (RBC), Pertumbuhan Premi Neto dan Profitabilitas Perusahaan Asuransi. Jurnal. Pekbis Jurnal, Vol.3, No.1, Maret 2011:391-405.

Ningrum, Arrum Dika Setia. 2104. Analisis Faktor-faktor yang Mempengaruhi Return On Equity Pada Perusahaan Asuransi Umum. Skripsi. Semarang: Fakultas Ekonomi dan Bisnis, Universitas Diponogoro.

Sopyan, Ahmad. (2010). Dampak Penerapan PSAK 108 Tehadap Tingkat Solvabilitas Minimum Perusahaan Asuransi Syariah: Studi Pada Unit Syariah PT. Asuransi Umum Bumi Putera Muda 1967). Skripsi. Jakarta: Fakultas Syariah dan Hukum, UIN Syarif Hidayatullah.

Standar Akuntansi Keuangan. 2012. Ikantan Akuntan Indonesia.

Sugiyono. 2013. Metode Penelitian Bisnis pendekatan Kuantitatif Kualitatif dan R\&D. Bandung: Alfabeta.

Supriyono, Agung Eko. 2013. Pengaruh Risk Based Capital terhadap Profitabilitas pada Perusahaan Asuransi Syariah: Studi Kasus pada PT. Asuransi Takaful Umum dan PT. Asuransi Takaful Keluarga Periode 2004-2010. Thesis. Universitas Pendidikan Indonesia. 
http://asuransibinagriya.blogspot.co.id 2011/11/disamping-sebagai-

bentuk-pengendalian.html

http://asuransisyariah.asia/product/4/

94/Pengertian-Asuransi-Syariah

http://bilongtuyu.blogspot.co.id/2013/

05/return-on-assets-roa.html

http://idbisnisretail.blogspot.co.id/201

1/02/pengertian-dasar-hukum-

sejarah-dan.html

http://www.bisnisasuransi.info/news risk

-based-capital 